\title{
Socializing the rain: human adaptation to ecological variability in a fishery, Mweru-Luapula, Zambia
}

\author{
Christopher M. Annear ${ }^{1}$ \\ Peter R. Waylen \\ Hobart and William Smith Colleges, USA \\ University of Florida, USA
}

\begin{abstract}
Rainfall drives fishery fertility in Mweru-Luapula, thus rainfall variability contributes to frequent changes in fishing catches. Fishers and traders have adapted their institutions to this variable ecology in a variety of ways, including learning to read the fishery for productive periods and practicing multiple modes of income procurement. By accurately identifying inter-annual, inter-decadal, and longer spans of rainfall trends, future high and low yields can be forecast. This article presents and analyzes annual rainfall in the fishery from 19161992 and quantitative fish market data comprised of observed fish catch numbers by species in three markets from September 2004 to September 2005. It uses political ecology to better understand fish production, trade, and subsistence in this South-Central African freshwater fishery. We combine qualitative analysis of fisher and marketer perceptions of the fishery and knowledge of rainfall patterns to show how human behavior is not "tragically" driven, but instead based on the state of the ecological, sociocultural, and socioeconomic environment at a given time.

Keywords: African freshwater fisheries, rainfall modeling, political ecology, Mweru-Luapula, Zambia, climate change

\section{Résumé}

La pluie est responsable de la fertilité de la pêche à Mweru-Luapula, en Zambie. La variabilité des précipitations contribue aux changements dans les populations et les prises de poissons. Les pêcheurs et les commerçants ont adapté leurs institutions à cette écologie variable de différentes manières, notamment en apprenant à lire la pêcherie pendant des périodes productives et en pratiquant de multiples modes d'acquisition de revenus. En identifiant avec précision les tendances pluviométriques interannuelles, inter-décennales et plus longues, il est possible de prévoir les rendements futurs élevés et faibles. Cet article présente et analyse les précipitations annuelles dans la pêcherie de 1916 à 1992 et des données quantitatives sur le marché du poisson comprenant les chiffres de capture de poisson observés par espèce sur trois marchés de septembre 2004 à septembre 2005. Il utilise une écologie politique pour mieux comprendre la production, le commerce et la pêche du poisson comme moyens de subsistance dans cette pêche en eau douce en Afrique du Sud-Centre. Nous combinons une analyse qualitative des perceptions des pêcheurs et des commerçants sur la pêche et une connaissance des régimes de précipitations pour montrer que le comportement humain n'est pas dicté de manière "tragique", mais est plutôt basé sur l'état de l'environnement écologique, socioculturel et socioéconomique à un moment donné.

Mots-clés: pêche en eau douce en Afrique, modélisation des précipitations, écologie politique, MweruLuapula, Zambie, changement climatique

\footnotetext{
${ }^{1}$ Dr. Christopher M. Annear, Associate Professor of Anthropology, Anthropology Department, Hobart and William Smith Colleges, 214 Stern Hall, 300 Pulteney Street, Geneva, NY 14456, USA. Email: annear "at" hws.edu. Dr. Peter R. Waylen, Professor of Geography, University of Florida, Gainesville, FL, USA. We gratefully acknowledge the editor and an anonymous reviewer for helpful comments, Robert A. Beutner for creating the map, and the many kind and hard-working Mweru-Luapula residents who shared their lives with us. Mwabombeni abanensu!
} 


\section{Resumen}

La fertilidad de las pesquerías en Mweru-Luapula está regulada por las precipitaciones, por lo que la variabilidad de las lluvias contribuye a cambios frecuentes en las capturas de los pescadores. Comerciantes y pescadores han adaptados sus instituciones a esta variable ecológica de diversas formas, incluyendo aprender del estudio de la pesca por periodos productivos y desarrollar múltiples opciones para obtener ingresos. Con la identificación precisa de las tendencias en lapsos interanuales e interdecadales de las precipitaciones, los rendimientos tanto altos, como bajos, pueden ser pronosticados. Este artículo presenta y analiza las precipitaciones anuales en la pesca en el periodo 1916-1992, además de los datos cuantitativos del mercado pesquero conformados por el número de capturas de pescado por especie observadas en tres mercados entre septiembre del 2004 y septiembre del 2005. Se utiliza ecología política para un mejor entendimiento de la producción, comercio y subsistencia en las pesquerías de agua dulce del sur centro de África. Combinamos análisis cualitativo de percepciones de pescadores y comercializadores acerca de la pesquería con el conocimiento de los patrones de las precipitaciones, para así demostrar cómo el comportamiento humano no se conduce "trágicamente", sino con base en el estado de los ambientes ecológico, sociocultural, y socioeconómico en un momento determinado.

Palabras clave: Pesquerías de agua dulce africanas, modelado de precipitación, ecología política, MweruLuapula, Zambia, cambio climático

\section{A fish follows water: the political ecology of a resilient fishery}

"Isabi, ilekonka amenshi" is a common saying by Zambians who depend on the fishery resources of Mweru-Luapula. It translates from Chibemba to English as, "fish follow water." The Mweru-Luapula allotrophic riverine fishery is a pulsed system in which fish-sustaining nutrients are most directly driven by flooding induced by rainfall (Bos, Kapasa and van Zwieten 2006; Jul-Larsen et al. 2003a; Zwieten, Goudswaard and Kapasa 2003). Therefore, fish and human communities that rely on the fishery more precisely follow rain, rather than water. It is upon this premise that we seek to better understand the patterns of rainfall over time in the Lake Mweru and, to a lesser extent, Lake Bangweulu basins, while also considering how fishers, fish traders, and many others in this cosmopolitan fishery have adapted to the inherent ecological variability of this system.

In this article, we map the region's regularly variable rainfall patterns, while also pinpointing periods of greatest interannual rainfall fluctuation, droughts, and trends in rainfall from 1916 to 1992 . We socialize these rainfall data by overlaying human fishing and trading adaptations, documented through qualitative and quantitative anthropological fieldwork conducted in 2003-2005, 2010, 2012, and 2015. Together, these complementary data explore how people live in the ecological and sociocultural waterscape that is the MweruLuapula fishery. Past policy has often been poorly conceived, because legislators have not recognized the nature of the ecological environment in which people live. Instead, such lawmakers have relied upon a localized version of "the tragedy of the commons" model (Hardin 1968), which expects and therefore legislates for ecological decline (Feeny et al. 1990). National newspaper accounts routinely call the alarm of fishery depletion and likely collapse of Mweru-Luapula. ${ }^{2}$

We present an approach using political ecology, studying small-scale fisher and trader political economy with an emphasis on environment dynamics, in particular, rainfall and nutrient passage through the fishery. Practitioners engage Mweru-Luapula with disparate and unequal means and access (Annear 2009; Verest 2013). By better recognizing the ecological state of its environment over time and human sociocultural relationships to it, fishery policy may be improved (Kolding and Zwieten 2011). This research connects to other regional studies in Southern Africa that focus on ecological drivers of human behavior and community resilience in response to variable environments (Aarnink, Kapasa and Zwieten 1993; Jul-Larsen et al. 2003a, b).

\footnotetext{
${ }^{2}$ An assortment of reports and articles conveying or representing this perspective include such titles as: "U.S. economist hails state over fish ban," Zambia Daily Mail, 2005; "Lake Mweru fish plunder worries fisheries official," Zambia Daily Mail, 2004; "State fears fish depletion in Luapula Lakes, Rivers," Zambia Daily Mail, 2004; "Kalifungwa explains low catches of fish in Luapula," The Post, 2005; and, "Fishing industry has collapsed says Machungwa," The Post, 2004.
} 
The Mweru-Luapula freshwater fishery exhibits high, but regular volatility due to climatic, internal ecological, and human pressures (Zwieten, Goudswaard and Kapasa 2003). Yet, until recently, biologists, and more importantly, policymakers, have focused their attention and recrimination only on human fishing pressure as causation for uneven fish catches over time. Fish stock numbers that typically vacillate from year-to-year have been used as evidence of a degrading fishery (e.g., Chisupa 2004; Kaswende 2005; Malama 2004), although longer term views of the fishery show sustained fish biomass over time (Zwieten, Goudswaard and Kapasa 2003).

Despite its shortcomings (Beverton and Holt 1957; Harley, Myers and Dunn 2001; Paloheimo and Dickie 1964), Catch Per Unit Effort (CPUE) is routinely cited by Zambian government officials as the statistic that indicates decline or even the "collapse" (Moonze 2004) of Mweru-Luapula. It is an arithmetic gauge that projects the kilograms of fish of various commercially significant species that would be caught on a single night in a $100 \mathrm{~m}^{2}$ net of typically used mesh sizes. This statistic is an extrapolation based on a limited series of gillnet-surveys undertaken at irregular time intervals, usually due to erratic funding streams necessary to execute them. ${ }^{3}$

In the case of the Mweru-Luapula fishery, CPUE numbers seem to show an alarming decline throughout the $20^{\text {th }}$ century (Zwieten, Aarnink and Kapasa 1995; Zwieten and Kapasa 1995). In some notable cases, certain valuable commercial species, such as the Luapula salmon (Labeo altivelis) in the 1950s were not just reduced, but disappeared entirely from the region (Annear 2006; Gordon 2006; Musambachime 1981). ${ }^{4}$ Most cursory observers of the Mweru-Luapula know little else about the fishery than to rely on conclusions based on apparent CPUE trends, and therefore presume that these data confirm the conventional axiom that common property resources (CPRs) with little to no external management collapse from the pressure of ever-increasing human predation.

In 1968, Garrett Hardin articulated the modern definition of the Malthusian model he called the tragedy of the commons. In his article of the same name, Hardin argued that rational choice in a common property resource inevitably leads to overuse and lack of restraint by its users. Therefore, the single option available to an individual is to maximize extraction of the resource, because by demurring he effectively steals from himself and gives to another - while the commons would be degraded either way. Hardin, in essence, argues that the only rational choice available to a resource user is to cause inevitable catastrophe in the open-access resource. Further, since by this reasoning users cannot be trusted to safeguard their own livelihood resource base, an external actor should govern it for them. The options he presented were privatization or governmental management.

The concept of the tragedy of the commons has since been widely critiqued by scholars. Brox (1990) and Feeny et al. (1990) show that Hardin's Common Property Theory is an analytical rather than empirical model, and is therefore an inadequate diagnostic and policy application tool for fishery management. Furthermore, empirical research has shown that few if any CPRs are open-access in practice. Research that is unbiased by Hardin's Malthusian paradigm often leads to insights, such as the capacity of inland fisheries to absorb under-capitalized economic migrants without overwhelming the ecological system (Brox 1990; McCay and Acheson 1987). This process is evident in Mweru-Luapula (Annear 2009; Gordon 2005; Verelst 2013). During 1980s migration into the region, fishers initiated a thriving freshwater sardines commercial fishery (Gordon 2005; Scullion 1985; Zwieten et al. 1996). Zwieten, Goudswaard and Kapasa (2003) characterize Mweru-Luapula as a lake-river system of surprising and hopeful resilience shown by maintained fishery biomass over the prior 40 years. This lake-river system represents a "dynamic fishery" (Goudswaard 1999) that is resilient in response to vicissitudes of climate and human pressure.

Despite these corrections in academic literature, Malthusian thinking has been and remains the foundation for ninety years of colonial and postcolonial legislation of Zambia's fisheries (Annear 2006). This legislation continues to promote formal commercial fishing effort as the solution to perceived overfishing, while condemning informal and non-market subsistence activities as its cause. The specific laws intended to

\footnotetext{
${ }^{3}$ Gillnet surveys have been quite inconsistent and do not relate to a single standard, with the exception of those undertaken with the support of the Netherlands Development Organization (SNV) in the 1990s.

${ }^{4}$ See section 3 for further discussion of the Luapula salmon.
} 
regulate the Mweru-Luapula fishery are drawn almost word-for-word from the Fisheries Act enacted in 1974, which, in all intents and purposes, merely rewrites the same rules found in the colonial Central African Federation era Fish Conservation Act of $1955 .{ }^{6}$

Contrary to such legal treatment, the population of fishers and fish traders operating in Mweru-Luapula is neither monolithic or equitable. These laws construct a legal and political environment that treats fishery practitioners differently according to status, capital accumulation, political-connectedness, and geography. Political ecology provides a lens to see the differential vulnerability, for example, of young male fish hands who rent boats to gain access to Lake Mweru, compared to their more capitalized vessel owners; the relative legal safety of politically-connected headmen on fishing prohibited lake islands versus the hand-to-mouth female "suitcase traders" who peddle fish during the annual closed fishing season; and the fishers who catch large commercially valuable fish for sale, but who can only buy cheap chibalebale "fish in a bowl" for their own consumption (see section 4).

\section{Mweru-Luapula ecology}

The Mweru-Luapula fishery comprises two contiguous areas encompassing a total of four strata, each biologically different but ecologically, economically and, socially interdependent. These are Lake Mweru (stratums 1, 2 and part of 3) and the Luapula River (part of 3 and Stratum 4, see Figure 1). Zambia and the Democratic Republic of the Congo (DRC) share the fishery. Of the 2,748 miles $^{2}$ total area of the MweruLuapula, Zambia controls 52\% (1,594 miles). Approximately 60 miles long (on a north-south axis) and 25 to 30 miles wide, Mweru is a relatively shallow lake, which gets progressively deeper as it stretches northward (from 10-15 feet to 120 feet at its deepest). Two important rivers flow into Lake Mweru: the Luapula at the southern end and the Kalungwishi on its eastern shore, while the Luvua River in the north flows out into the Lualaba and eventually Congo rivers of the DRC. The Mweru-Luapula watershed comprises the lower Luapula River, which extends 101 miles $(163 \mathrm{~km})$ northward from Mambalima Falls through Lake Mweru. The width of this stretch of the Luapula River fluctuates seasonally, from 400 yards $(366 \mathrm{~m})$ wide when confined to its banks in May and June to floods that reach 3 to 11 miles east in December and January $(4.8-17.7 \mathrm{~km})$. Its depth varies between 15 to 35 feet (4.6-10.7 m) (Carey 1965; Maboshe 2004).

It is due to this lake-river composite that Mweru-Luapula is termed to be an allotrophic riverine lake (Kolding 1994 cited in Zwieten, Goudswaard and Kapasa 2003), which categorizes it as a pulsed or seasonal system. Among the more striking characteristics of such a system is its inherent variance. It is governed by periodic inputs or pulses of nutrients, thereby causing it to be especially fertile and nutrient-rich in certain seasons and years, but not others. Such an ecological temperament endows resiliency, but also makes it potentially vulnerable to broader climate trends that affect inter-annual water levels (Zwieten, Goudswaard and Kapasa 2003).

Lake water level depends largely on rainfall. It correlates positively to nutrient levels and therefore fishery production in Lake Mweru (Zwieten, Goudswaard and Kapasa 2003). Activity in the fishing sector (i.e., numbers of fishers and fish traders active in market exchange) can therefore be expected to relate to the periodic high fishery yields associated with good rains (Zwieten, Aarnink and Kapasa 1995). This causal relationship, however, is not immediate. It takes typically two years for rainfall in a given season to affect fish catches (Zwieten, Goudswaard and Kapasa 2003). Similarly, the livelihoods of individuals and communities that depend on this inland fishery may be threatened by changes in precipitation patterns that many climate change studies observe or predict (Fauchereau et al. 2003; Hulme et al. 2001).

\footnotetext{
${ }^{5}$ Cap. 200, 1974.

${ }^{6}$ Cap. 263, 1955.
} 


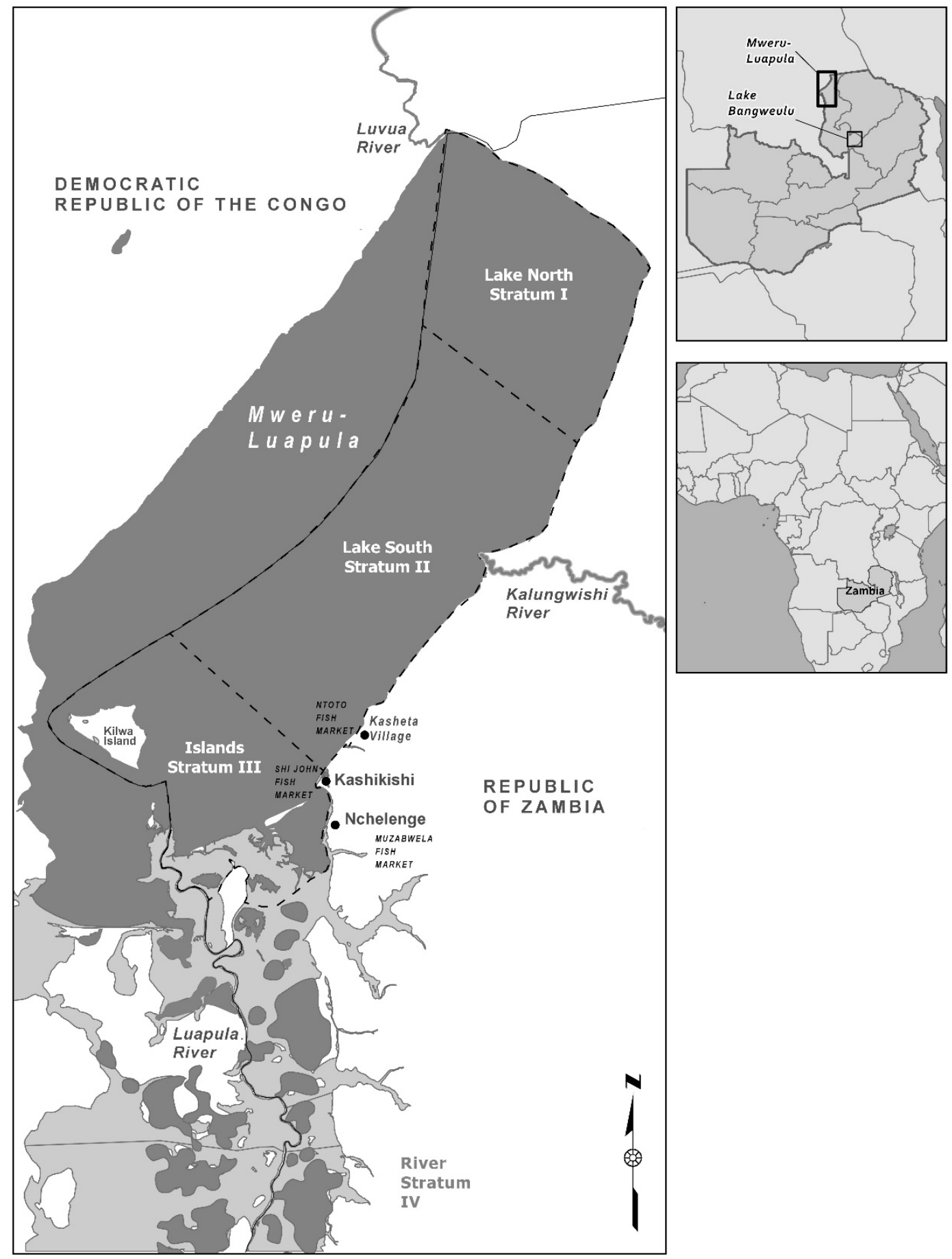

Figure 1. Mweru-Luapula with stratum demarcations and fish market sites. Map created by Robert A. Beutner using open source content (2019). 
As stated by Jul-Larsen et al. (2003a: 58), "The most conspicuous external drivers of nutrient inputs... are long-term, inter-annual and seasonal fluctuations in water level and river inflow." Although Lake Mweru water levels for certain years, as in 1993-1994, have been reported to be excessively low (Bos, Kapasa and Zwieten 2006), it does fit a general pattern if there had been above median rainfall two years earlier. Therefore, relative lake level fluctuation indices should theoretically predict lake nutrient levels and relative fish stock density.

Two interrelated human social problems arise from the inherently high variability of such a pulsed system. One stems from the deterioration or loss of complementary productive alternatives to fishing and, the other, the vulnerability of the fishery in cyclically lean years to overfishing, which may be getting more extreme with macro climate change. In high fertility years Lake Mweru can sustain intensive fishing pressure, but it becomes vulnerable to excessive and targeted effort during extended periods of poor production (Zwieten, Goudswaard and Kapasa 2003). However, in present day few people fish or trade fish exclusively. Most practice several additional livelihood strategies that complement fishing activities, such as non-fish commodity trading, farming, and provision of services. This common practice of conducting multiple livelihood strategies is also evident in the composition and structure of villages, which have adapted over time to meet the needs of a mixed and transient population. Annear's 2015 (unpublished) housing survey in Kabosha Village of Kashikishi township indicated that approximately $30 \%$ of permanent residential structures were occupied by renters or were available for rent by the owners who resided elsewhere.

\section{A fish follows (rain)water: the relationship between rainfall and fish catches}

Rainfall and consequent water level are central drivers and predictive indicators of catch robustness in Mweru-Luapula. Williams (1972) noted a positive relationship between water level and fish catches. Further, he proposed that the rainfall in a given year predicts with accuracy, catches of medium- and slow-growth fish species two years later. Zwieten, Goudswaard and Kapasa (2003), likewise showed a correlation between spikes in cichlid catches preceded two years earlier by high water levels.

Since it is a pulsed, seasonal system Mweru-Luapula is highly reliant on the vicissitudes of annual rainfall patterns. It is governed by periodic inputs of nutrients, thereby causing it to be especially fertile and nutrient-rich in certain seasons and years (Jul-Larsen et al. 2003a). These pulses draw in nutrients through flooding, while distributing them to its four ecological strata zones. This process sets the conditions for high and low breeding years, depending on the life cycles of various endemic species. Rainfall is therefore a particularly important indicator of fishing production in Mweru-Luapula, but also for livelihoods throughout Zambia and the continent (Grimes et al. 2003; Nawa 2000).

Figure 2 describes the spatial distribution of mean annual precipitation across the area, which ultimately contributes water to the outflow of Lake Mweru based on historic rainfall records from 60 stations in and around the Lake Mweru basin. ${ }^{7}$ The pattern is concentric with values in excess of $1400 \mathrm{~mm}$ centered over the Bangweulu wetland complex descending to $1100 \mathrm{~mm}$ near the Muchinga Mountains in the east and the Kalanga Mountains to the west (see map above). Rainfall is highly seasonal, focused on the austral summer from about November to April, driven by the southward migration of convection associated with the Inter-tropical convergence zone (ITCZ), which may be drawing in moisture from both the Indian and Atlantic Oceans. The latter process may be greatly aided by the extensive forests of the Congo basin. Regions in the northwest experience a slightly longer rainy season with a slight bimodality associated with the southward and northward returning migration of the ITCZ (Dezfuli and Nicholson 2013; Nicholson and Dezfuli 2013).

\footnotetext{
${ }^{7}$ Global Historical Climatology Network, http://www.ncdc.noaa.gov/data-access/land-based-station-data/land-baseddatasets/global-historical-climatology-network-ghen
} 


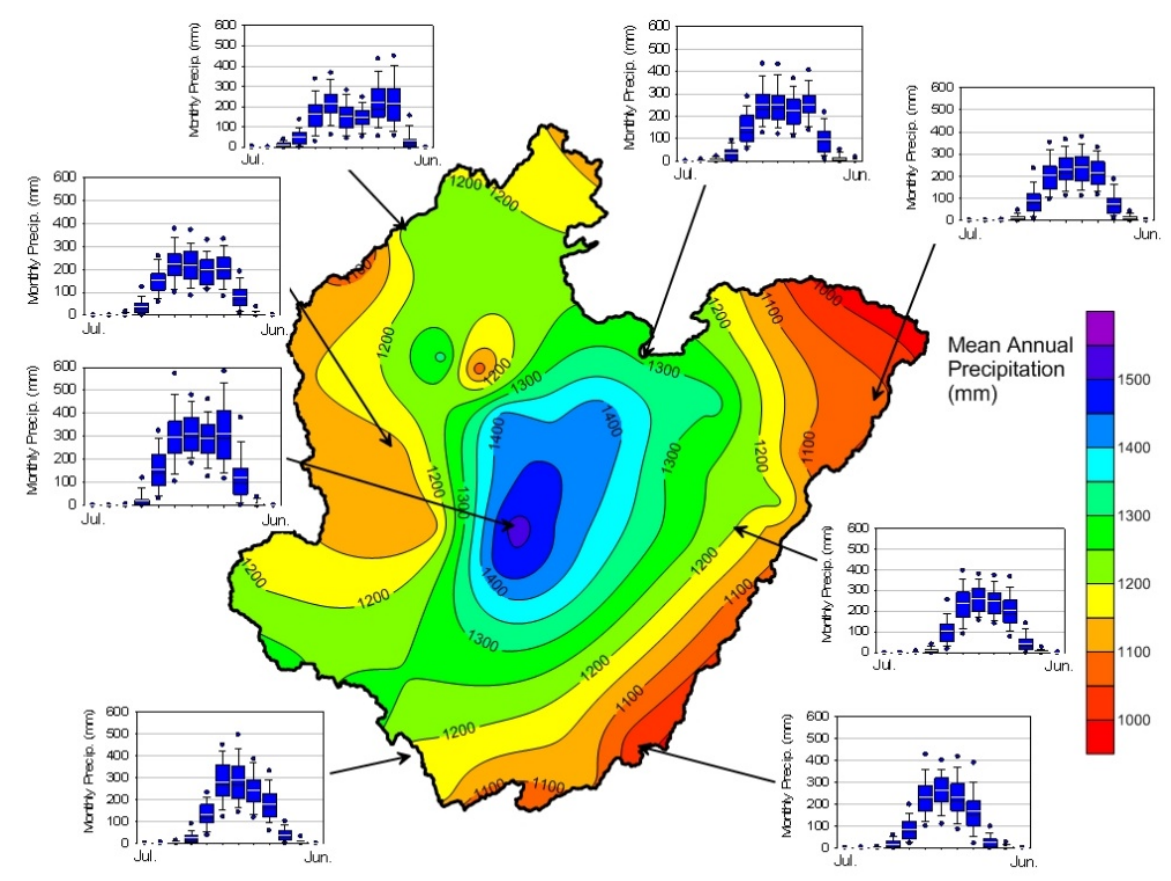

Figure 2: Mean annual precipitation by geographic space.

Figures 3 and 4 illustrate this linkage between historic basin inputs and lake levels 1955-1996 (Bos, Kapasa and Zwieten 2006). The upper chart, Figure 3, displays the marked interannual fluctuations of both annual time series and strongly suggests that the two experience similar amplitudes of change, but these are out of phase with one other. This impression is statistically validated in the lag-cross correlegram in the Figure 4 lower diagram which displays the strength of the correlation between annual lake level and the estimated basin precipitation, lag 0 , the previous year, lag 1 , two years previously, lag 2 , etc. The most prominent feature of the correlogram is the high and statistically significant $(\alpha=0.05)$ positive correlations at lags 1,2 and 3 , similar to the observations that fish catches reflect rainfalls two years previously, in this case reflected in delayed increase in lake level as water collected over the bulk of the basin is delayed as it passes through the massive Bangweulu wetland complex.

The correlogram also reveals a characteristic which has not been observed in fish catches, but which by extension is probably relevant. The rainfall/lake level process appears to be a semi-periodic one during this period, with a frequency of oscillation of about seven years as indicated by the statistically significant positive correlations at a lag of about 8 years, in addition to those mentioned above. Although the computed correlation does not quite make the required level of significance, there are indications of negative correlations at a lag of 5 years. This is a correlogram of a typical oscillatory lagged process with a frequency of about 7 years and may be driven by low frequency changes in external forces such as El Niño Southern Oscillation, in the Pacific Ocean, the Indian Ocean Dipole, sea surface temperatures in the Atlantic, or some complex interaction between these (Camberlin and Philippon 2002; Jury, Matari and Matitu 2009; Marchant et al. 2007; Plisnier, Serneels and Lambin 2000; Williams and Hanan 2011). Such semi-periodic behavior is also likely to be reflected in the lake ecosystem and the local fisheries (Roy, Holt and Barfield 2005). 

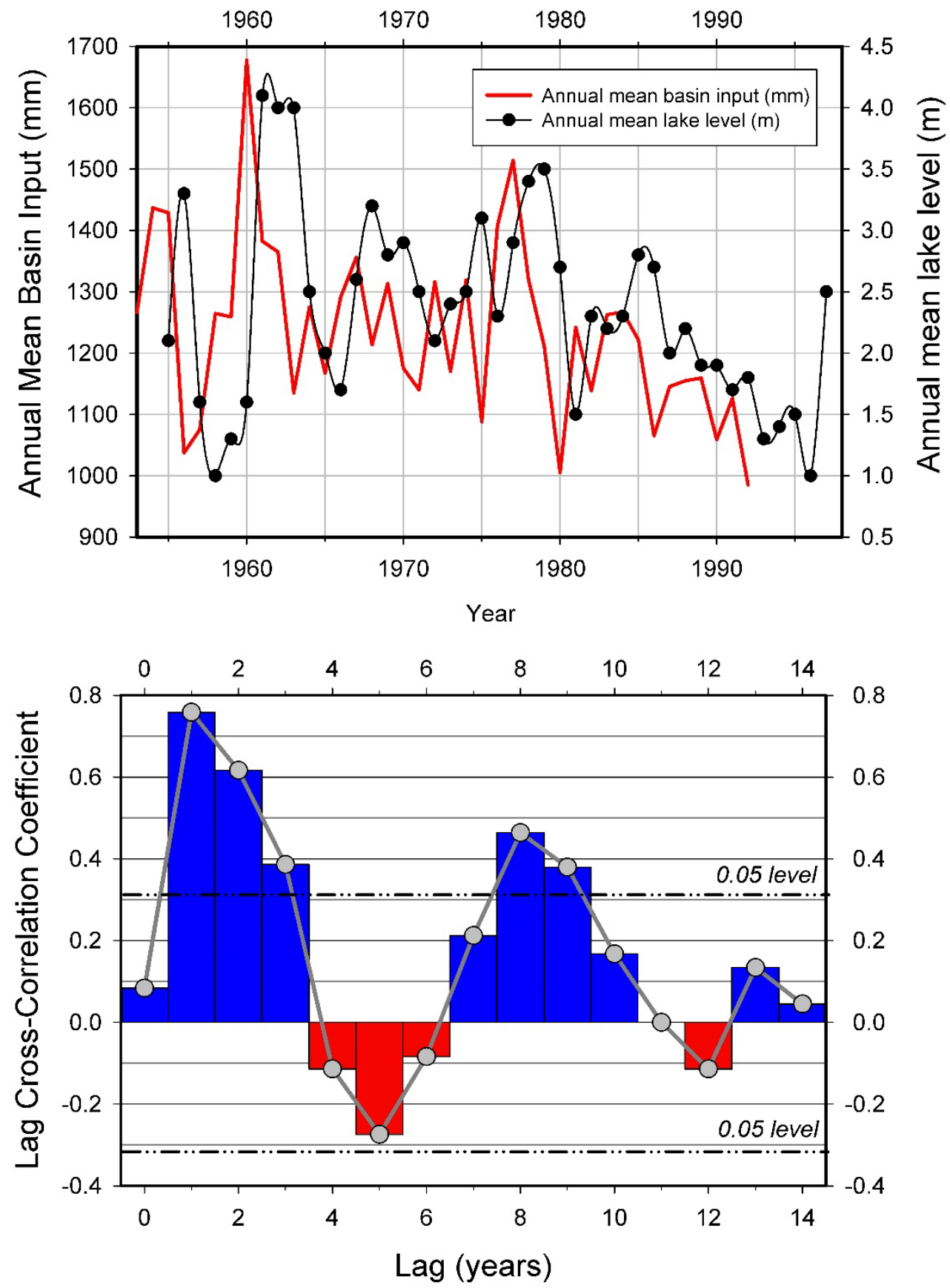

Figure 3: Annual rainfall and lake level, 1955-1996.

Figure 4: Strength of correlation between rainfall and lake level in reference to lag years. 
The basin precipitation, 1916-1992 table, Figure 5a below, shows 76 years of rainfall data with interspersed social and fish catch events to illustrate this point. The disappearance of the Luapula salmon (Labeo altivelis), enactment of landmark Fish Act regulations, and then the subsequent easing of government fishery management enforcement just after Zambian independence occurred during low productivity fishing years that followed lower than average rainfall two to three years earlier-or, in the case of the regional loss of Luapula salmon, chronic drought conditions.

Catches of Luapula salmon declined from over 50\% to 3\% of fish catches between the years of 1947 to 1953 due to colonial regulations that favored immigrant Greek fishermen and their use of nets that stretched across the mouth of the Luapula River in order to catch the migratory fish (Annear 2006; Gordon 2006; Musambachime 1981). Moreover, starting in 1964, the First Republic government of Zambia effectively loosened fishery regulation enforcement in order to curry favor from the Mweru-Luapula populace following years of suspicion and mistrust of colonial fisheries policies. Nevertheless, these events occurred against the ecological basis of relatively poor fish takes following low rainfall in preceding years. Note Figure $5 \mathrm{~b}$, which highlights especially high variability frequency from 1945 to 1965 . The events that established current fishery legislation and policy occurred during this period (Annear 2006).

\section{Basin Precipitation, 1916-1992.}

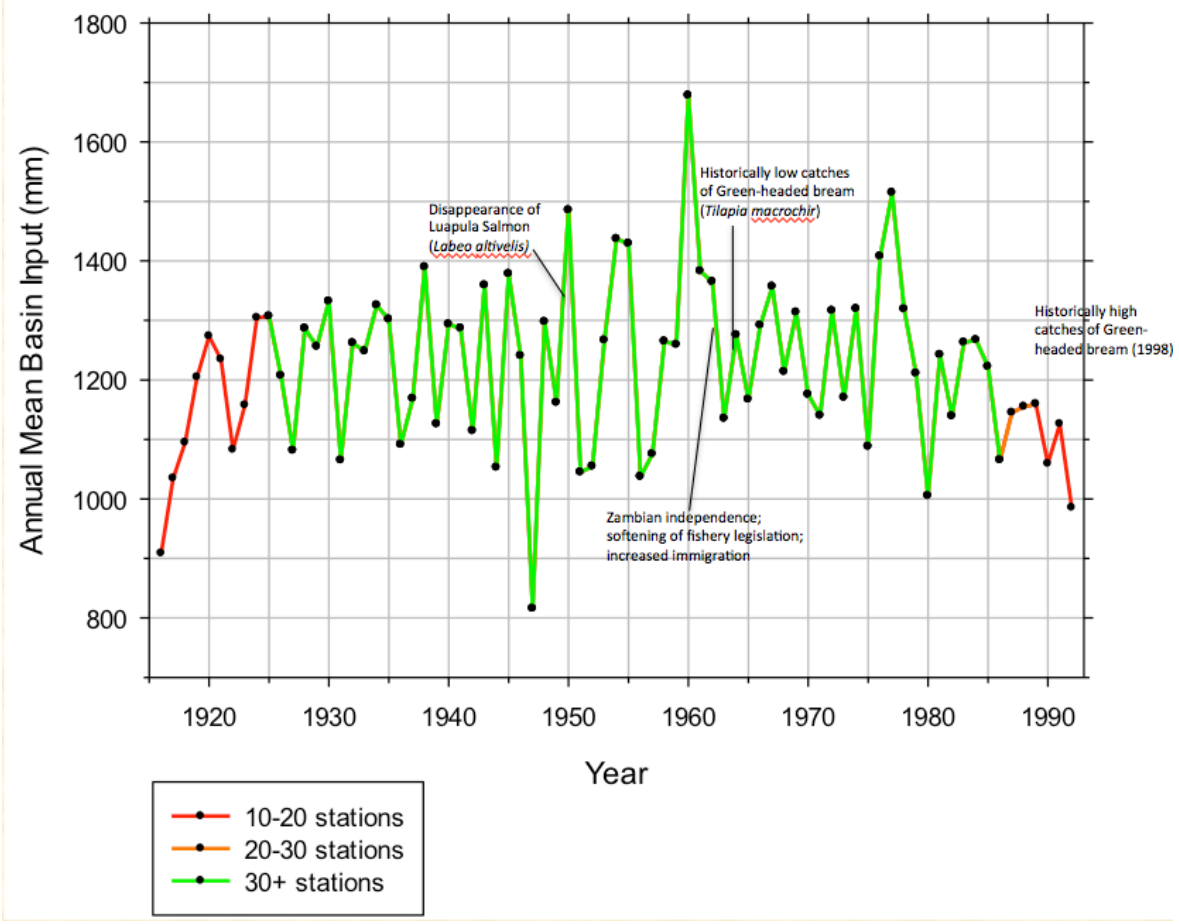

Figure 5a: Basin precipitation, 1916-1992. 


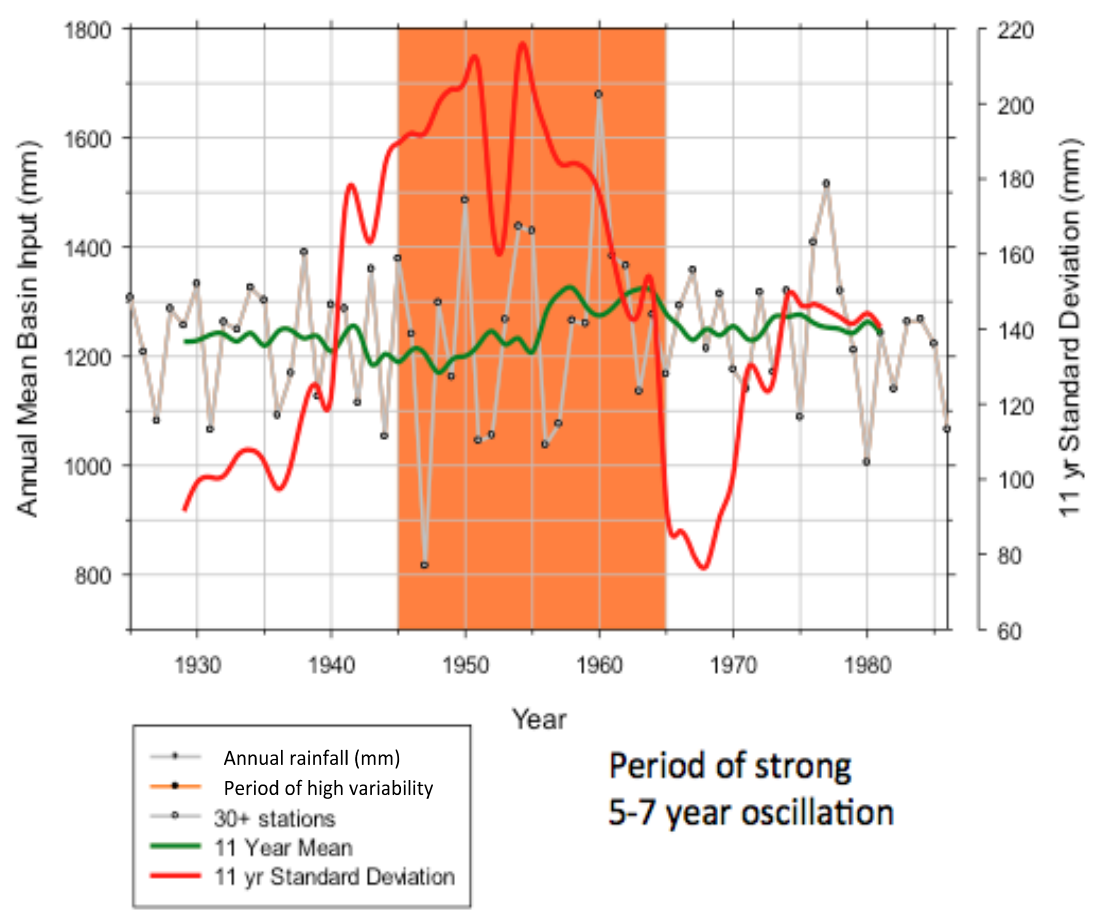

Figure 5b: Basin precipitation, 1925-1986.

During this twenty-year period and often into the present, governing officials and scientists explained poor fish catches as a function of overpopulation and selfish fishing effort. As an example, the particularly abysmal 1966 annual catch of Green-headed bream (Oreochromis macrochir), the most commercially valuable species throughout this era, spurred declarations of fishery decline and further bolstered belief in the tragedy of the commons model. While not surprising, this "tragic" narrative propelled policy that swung from punitive and exclusionary (i.e., the Fish Act of 1955) to under-enforcement of existing regulation following Zambian independence in 1964. The contemporary policy of comanagement, which is implemented by government officials, local customary leaders, and fisher representatives, is similarly weakened by reliance on this singular Malthusian explanation (Annear 2009).

Despite persistence of the tragedy narrative, rumors of the Green-headed bream's demise were obviously premature, as robust harvests have periodically followed years in which it was hardly seen. Furthermore, Green-headed bream catches exhibit more recent increase in length. Zwieten, Goudswaard and Kapasa (2003) attribute this apparently contradictory trend to fisher use of progressively smaller net sizes due to expectations based on fishing down trends. By adapting to the dynamic fishery and thereby targeting medium-sized fish, fishers are in effect deselecting and thus reducing pressure on larger individuals of this relatively fast-growing species. $^{8}$

\footnotetext{
${ }^{8}$ Similar results have been observed in the Maine, USA lobster fishery, where fishers have initiated a highly successful management regime by targeting medium-sized lobsters to the exclusion (and benefit) of small, first-molt, and large robust-
} 


\section{Chibalebale: economic stratification and narratives of decline}

We eat chibalebale due to lack of big fishes. If you buy chibalebale you find it mixed with snails. God made them as foodstuffs for big fishes. Maybe big catfish and small catfish eat chibalebale. We just eat what they eat.

-Headman Shi John, Shi John Village, Kashikishi ${ }^{9}$

Marketers were complaining about low catches. They said they are failing to buy fish for selling because of scramble for it. They said this is a clear sign of serious decline of fish.

-Michael Timu, Fisheries Officer, Shi John Market, Kashikishi ${ }^{10}$

Many fishers and fish traders complain of catching or selling large, succulent fish such as Green-headed (Oreochromis macrochir) and Red-breasted bream (Tilapia melanopleura), but of lacking the economic capacity to eat them. This is especially so when catches of these larger, commercially desirable fish are poor. As prices for these fish go up due to unmet consumer demand in urban cities throughout the South-Central African region, local fishers and traders turn to cheap and affordable chibalebale.

The terms chibalebale and akashebondwe or akashebondo are recent linguistic inventions coined to describe the product of catching and selling assorted juvenile fish. These terms refer not to a single species, but instead to the quantity of fish being sold. Chibalebale translates literally as a "things in a dish," meaning assorted juvenile fish sold by the small dish or bowl-full for the US\$ equivalent of 10-20\&. The most common modern method of collecting chibalebale is to stitch together a few mosquito nets, called akashebondwe when used for this purpose. Women and children also use two-meter lengths of chitenge wrap cloth as catchall beach seine nets to gather chibalebale at the shoreline.

Sometimes perceived to be filling a market niche previously occupied by adult fish of greater size and prevalence, chibalebale has been viewed by Department of Fisheries officers as an example of expected degradation of the ecological and economic health of the Mweru-Luapula fishery. These officials said such mounds of juvenile fish represented another way that fishers were destroying their own livelihoods. ${ }^{11}$ As they condemned those selling chibalebale, Department of Fisheries officers equally praised fish traders when they were not observed in the market over a period of weeks. Michael Timu (in epigraph above) declared that, "fishers themselves have put their hands together to conserve the resource by stopping chibalebale fishing." 12

However, our research indicates that these associative connections were not descriptions of a biophysical truth revealed over time, but instead situational expressions of frustration that were being interpreted a certain way by linking it to a pre-established narrative. Chibalebale is not universally condemned. Fish market records show that most days it was sold openly, yet only rarely did fish buyers disapprove of it. When chibalebale was criticized, it only tended to be on days when larger fish landings were poor:

Fishing still not yet picked [up]. Catches are still low. Fish prices are high: inflation. With the new fishing strategy on chibalebale trade that is fish trading of this species [sic] on the market. The general response was a sad situation. The reason is simple. Chibalebale is highly bought by many households because it is cheaper. ${ }^{13}$

breeding individuals, respectively (Acheson 1988, 2003; Acheson and Wilson 1980).

${ }^{9}$ Interview, Headman Shi John September 6, 2004.

${ }^{10}$ Fish market survey entry, August 29, 2005.

${ }^{11}$ Such arguments are not exclusive to Zambia. Recent academic articles (McLean et al. 2014; Minakawa et al. 2008) and a newspaper story (Gettleman 2015), among others, project similar concerns.

${ }^{12}$ Fish market survey comment, Muzabwela Market, Nchelenge, August 8, 2005.

${ }^{13}$ Fish market survey comment, Muzabwela Market, Nchelenge, May 1, 2005. 
Reproductive age adults of various commercially relevant fish species in the Mweru-Luapula fishery may be caught in high numbers one year, then be virtually absent from the fishing record the next. There has also been a shift in the past two decades toward fast-maturing species such as the Silver alestes (Alestes macrothalmus), a 10-20 centimeter open water species that is known for its dramatic jumping during spawning, and chisense, a lake sardine (Microthrissa (Poecillothrissa) moeruensis) that is reproductive within nine months and adult at 5-7 centimeters (Gordon 2005; Scullion 1985; Zwieten et al. 1996). In reference to the fish market survey presented in section 5 below, the species that passed through each of three southern Lake Mweru markets in 2004 and 2005 varied in type, but were similar in age. Based on species length, there is strong indication that most fish hauled up in nets are about two years old and have already reproduced at least once (Zwieten, Goudswaard and Kapasa 2003). ${ }^{14}$

\section{5. "Low catches—bad weather" ${ }^{15}$ : regular variability in a chaotic fishery}

While fishing will have an effect on size structure and species composition of fish community [in the Mweru-Luapula fishery], fishing alone does not determine it in this system where large recruitment peaks occur as a result of irregular large (to extreme large) flood pulses. (Zwieten, Goudswaard and Kapasa 2003: 27)

The Mweru-Luapula lake-river system fluctuates on a daily, seasonal, and annual basis in terms of nutrient flows, flooding and water level, winds, and vegetation density. ${ }^{16}$ Such biophysical flux is a regular aspect of the fishery, to which fishers and traders adapt, even if they are unable to predict the precise consequences of a particularly heavy rainy or windy season. People who derive their living from the fishery are intimately aware of shifts and changes that occur. For example, after a poor take from Lake Mweru, a trader suggested that the relative cycle and light of the moon affected certain species: "Catches are bad today because of previous night rough weather. The other reason why catches are bad-the moon is not yet strong." ${ }^{17}$ This woman expected many variables to be at play that might affect the relative success of a night of fishing, and she incorporated this knowledge into her evaluation of a given fish catch. While a legislator might conclude that a poor night's haul proves fishery decline, a fish trader recognizes that weather and the lunar cycle could enhance or reduce the number of fish available for sale when she arrives at the market in the morning.

Fishers and traders as well as fish consumers manage their expectations based on general knowledge of the ecological variability of Mweru-Luapula. People often make comments in reference to good and bad catches that reflect hopefulness or frustration based on that day's yield. But it is rare to hear sustained grievances articulating a belief that the fishery is collapsing. Instead, people remark upon characteristics of the ecological fishery: rainfall, wind, water temperature and color, and the presence or absence of the moon. The discourse of "tragedy" fails to incorporate such locally recognized ecological dynamism.

The survey of three fish markets from Nchelenge to Ntoto Village (see map for locations), September 2004 through August 2005, exhibits the persistent variability of the Mweru-Luapula fishery in relation to ecology, seasonal and annual timing, and fishing effort that is specific to that locale. The following three charts

\footnotetext{
${ }^{14}$ The authors' fish market survey also verifies this conclusion based on data drawn from average fish species length per daily catch.

${ }^{15}$ Fish trader comment, Muzabwela Market, Nchelenge, October 11, 2004.

${ }^{16}$ The vegetation most commonly discussed by fishers is the indigenous hippo grass, which can choke off boat access to narrow channels and shallow fish breeding grounds. When this water plant prohibits access to certain prized species, fishers refer to it as "chibindo cha kwa Lesa", or God's closed season. Annear explores this in an article currently under review entitled, "God's closed season: fishing under divine and secular authority in Mweru-Luapula fishery, Zambia."

${ }^{17}$ Fish trader comment, Muzabwela Market, Nchelenge, November 17, 2004.
} 
(plus one enlarged view) show catches recorded three times weekly over a span of twelve months. ${ }^{18}$ Both Muzabwela and Shi John markets are located within close walking distance to long-distance transportation depots and to ice plants where fish traders can pay to freeze commercially valuable fish for transport to lucrative urban markets in Lusaka and the Copperbelt. Many long-distance traders considered the 2004-2005 year to be poor, even though records show many species of fish in significant numbers were available on a daily basis in all three markets.

Figures 6 and 7 illustrate this discrepancy between fish biomass and trader perceptions. They show appreciably high catches of Red-breasted bream, a mid-value commercial fish, but relatively meager landings of the prized Green-headed bream. A snapshot conclusion might suggest that the latter bream had been affected by intense fishing pressure and therefore would exhibit decreasing numbers with each passing season. As discussed earlier, this particular species has been a concern to fisheries biologists for decades, especially after the regional extinction of the Luapula salmon in the early 1950s (Jackson 1961), yet numbers of Green-headed bream continue to crest and trough cyclically as is expected in an allotrophic riverine system (Zwieten, Goudswaard and Kapasa 2003).

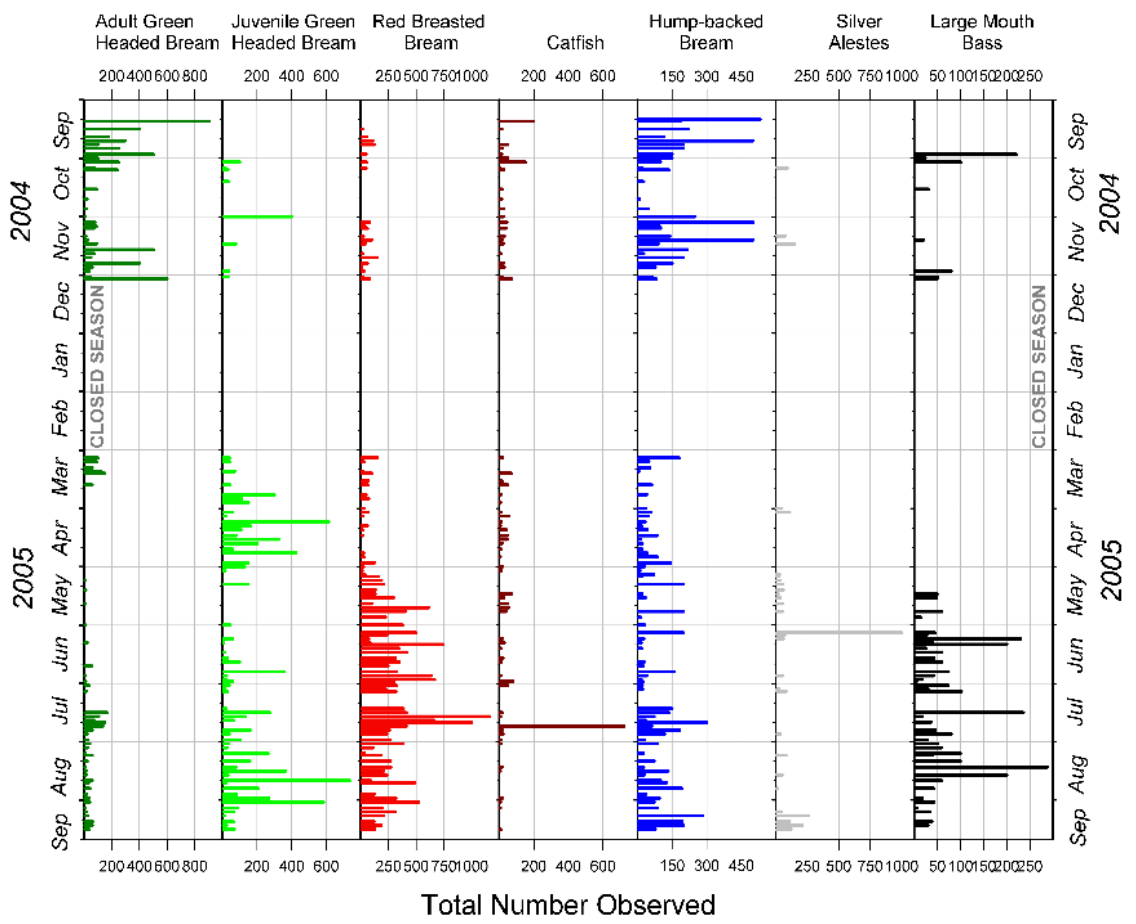

Figure 6: Fish catches, Muzabwela Market, Nchelenge, Zambia, 2004-2005.

\footnotetext{
${ }^{18}$ Due to the annual closed fishing season and their relative proximity to the Zambian Department of Fisheries regional headquarters, Muzabwela and Shi John markets each shut down from December first through the end of February. Therefore there is no record of fish catches in these markets during this stretch. However, data was available from Ntoto Market during the closed season, because, despite its illicit nature, trading continued throughout this period.
} 


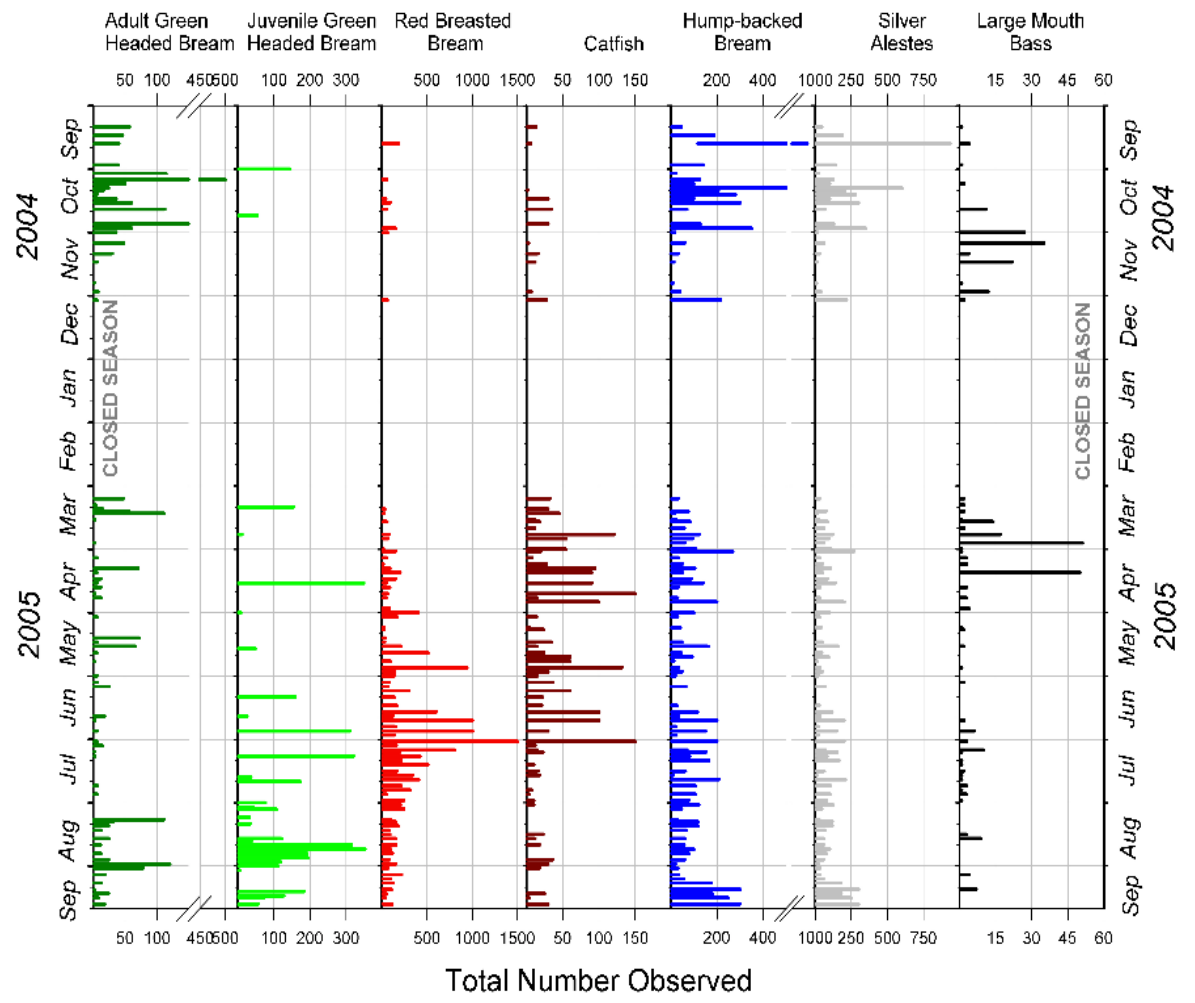

Figure 7: Fish catches, Shi John Market, Kashikishi, Zambia, 2004-2005.

All three markets demonstrate high variability in the fishery over a daily, weekly, and seasonal basis. Fish catches fluctuate due to weather, fishing pressure, health and availability of targeted stocks, and simply luck. These charts each show the extreme vicissitudes in fortunes that fishers and traders endure everyday. They also indicate the diversity of Mweru-Luapula ecology in a geographic span of just fifteen kilometers. While Muzabwela and Shi John markets exhibit significantly different catch compositions over the year, the numbers of fish caught is relatively similar. Contrast these two major markets to the catches documented in the more rural Ntoto Market, shown in Figures $8 \mathrm{a}$ and $8 \mathrm{~b}$. Whereas neither of the previous two markets recorded significant numbers of Silver alestes, Ntoto shows catches during the cold season months (June-October) that are ten times greater than the largest landings of the other markets at any time of the year. Moreover, even when discounting Silver alestes catches in Ntoto, six other species exhibit similar numbers and diversity to the other markets.

These market survey sites show one year, frequently and regularly throughout this period of time, with the exception in Muzabwela and Shi John markets of the annual closed season. Several conclusions can be drawn that relate to earlier descriptions of this ecological fishery. First, variability is normal. Second, not only is ecological variability to be expected based on general knowledge of the fishery, but it is evident in the catches that fishers row into markets everyday. Last, diversity in fishery ecology is showcased in even these proximal markets. 


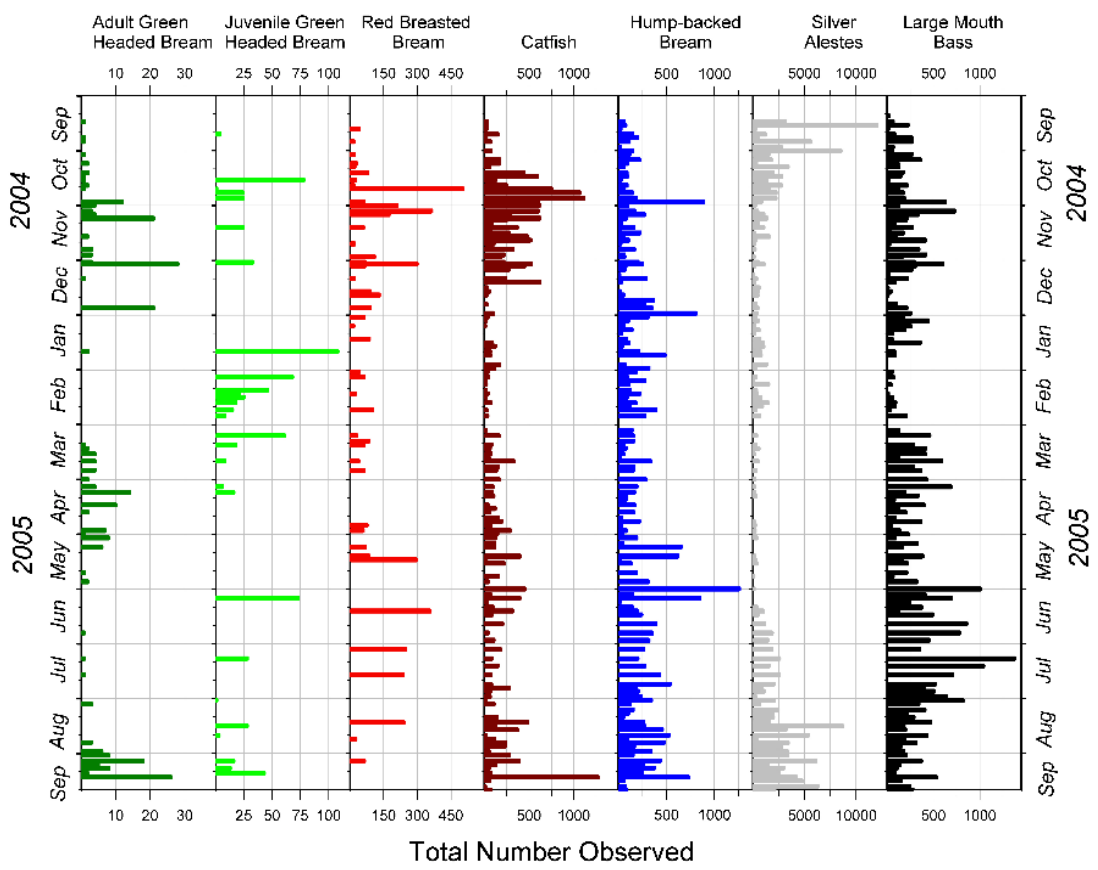

Figure 8a: Fish catches, Kasheta Market, Ntoto, Zambia, 2004-2005

\section{Ntoto Market}

September 2004-August 2005

Kasheta Village, Zambia

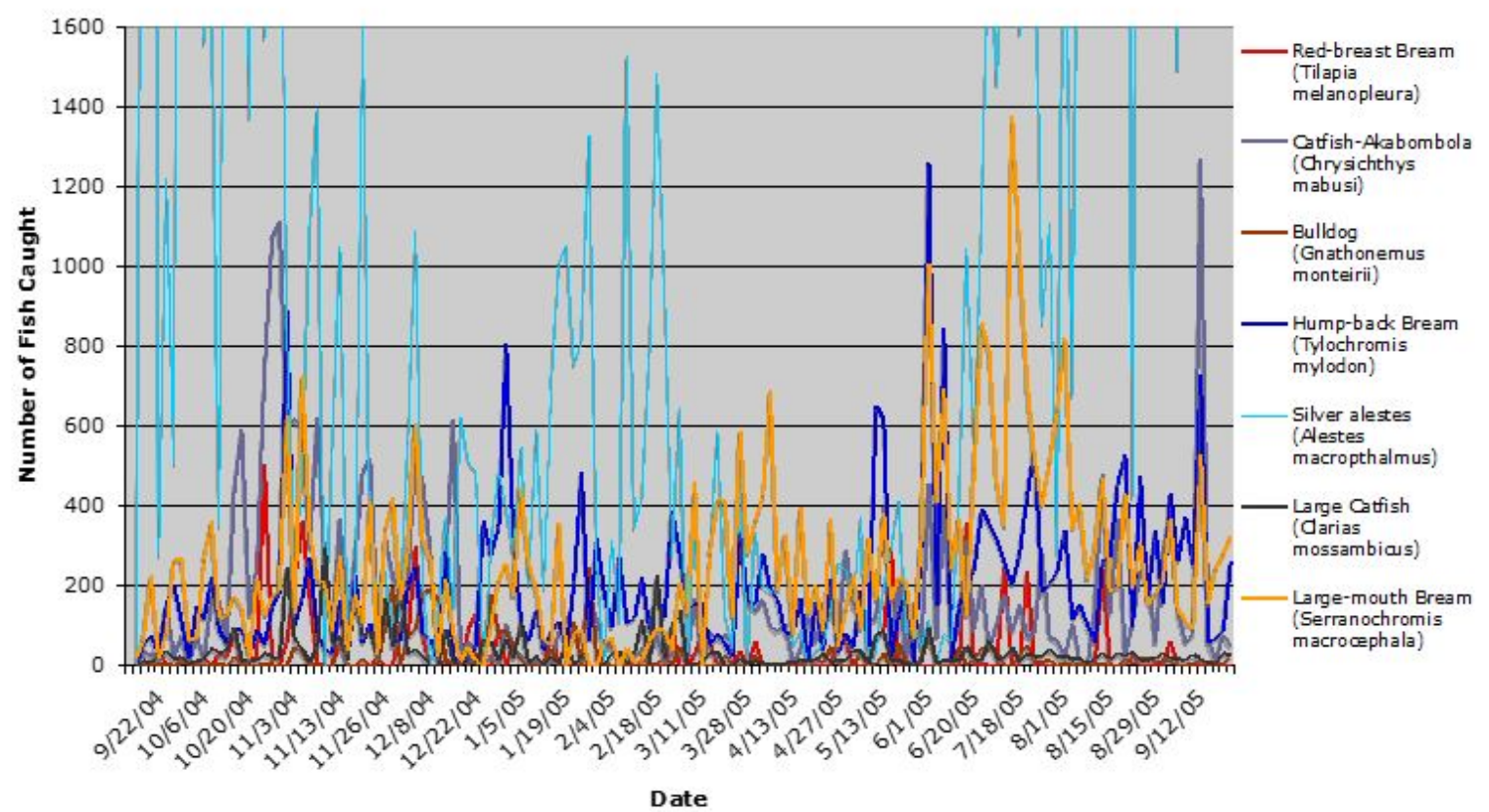

Figure 8b: Fish catches, Kasheta Market, Ntoto, Zambia, 2004-2005 (scale minimized). 


\section{Conclusion: chaos and resilience}

Carl Holling (1986) introduced the basic concept of ecological surprise into the repertoire of biologists at a time when many still believed that biophysical environments are systems that persist in predictable balanced states. Surprise occurs in an ecosystem when it behaves in a way that does not match expectation. When applied to Mweru-Luapula, Holling's important insight prompts a basic question. If much of past ecological research focused on identifying balance points and optimal resource extraction that nears but does not cross a threshold of collapse, what is an appropriate characterization of a biophysical environment that is in constant flux?

James Acheson and James Wilson (1980, 1996), among others, assert that extremely complex, multiple species fisheries that change frequently and frustrate prediction act chaotically. Chaotic systems, they argue, incorporate significant swings in individual species populations from season to season, but maintain an overall stability of biomass (Wilson et al. 1991). Moreover, this capacity to endure internal instability and maintain overall stability, endows resiliency against variable broader environments. Nevertheless, they warn that chaotic systems are extremely sensitive to "internal conditions" (Gleick 1997). Small changes can thereby generate quite large variations in the future state of the system.

Roy et al. (2005) took a long established model of biological populations (Holt 1985; Pulliam 1988) which views two habitats, one in which births exceed deaths (the source) and the other (the sink) in which deaths exceed birth. These habitats might be analogous to areas of the lake favorable to reproduction and those in which fishing (predation) dominates. Roy et al. demonstrate that when temporal (the lead lag relationship between rains and lake levels, and its semi-periodic nature) and spatial autocorrelation (the demonstrated expansion of the various habitats, particularly in the southern end of the river system) are present in such a source-sink system, they typically produce wide fluctuations in population sizes and growth rates, as appear to be present in the Mweru-Luapula. When viewed in the long-run, mean reproduction rates in such a system can appear to suggest danger of extinction, however with spatial autocorrelation and runs of good years, in which the population grows, the populations can rise to large sizes.

While variability does not portend fishery collapse in Mweru-Luapula, it does make fisher and fish traders' lives uncertain. We argue that fishing populations adapt to rainfall driven season-to-season caprice in the fishery by diversifying their livelihood income and living in neighborly communities that accommodate a high degree of transience. This article works to show that the state of the fishery cannot be realistically characterized by relying on sporadic gillnet surveys that calculate CPUE. Fish catches can fluctuate widely from day-to-day and typically from year-to-year. Such variance may be viewed as minor and often quite positive from an ecological point of view if it appears in tandem with other factors present in a fishery that behaves like Mweru-Luapula. Moreover, to someone who survives hand-to-mouth on marginal fishery profits, this sort of oscillation translates into a productive, if anxiety-inducing, resource base.

\section{References}

Aarnink, B.H.M., C.K. Kapasa and, P.A.M. van Zwieten. 1993. "Our children will suffer": present status and problems of Mweru-Luapula fisheries and the need for a conservation and management action plan. Bujumbura: UNDP/FAO Regional Project for Inland Fisheries Planning Development and Management in Easter/Central/Southern Africa.

Acheson, J.M. 1988. Patterns of gear change in the Maine fishing industry: some implications for management. Maritime Anthropological Studies 1: 49-65.

Acheson, J.M. 2003. Capturing the commons: devising institutions to manage the main lobster industry. Hanover and London: University Press of New England.

Acheson, J.M. and J.A. Wilson. 1980. A model of adaptive behavior in the New England fishing industry. University of Rhode Island/University of Maine Study of Social and Cultural Aspects of Fisheries Management in New England Under Extended Jurisdiction, Volume III. National Science Foundation.

Acheson, J.M. and J.A. Wilson. 1996. Order out of chaos: the case for parametric fisheries management. American Anthropologist 98(3): 979-994. 
Annear, C.M. 2006. Legislating 'Liverpool': the role of law in the development and conservation of the MweruLuapula Fishery, Zambia. In Seidman, A., R.B. Seidman, P. Mbana and H. Hu Li (eds.). Africa's challenge: using law for good governance and development. Trenton, NJ: Africa World Press.

Annear, C.M. 2009. Navigating constricted channels: local cooption, coercion, and concentration under comanagement, Mweru-Luapula fishery. Journal of Political Ecology 16: 34-48.

Annear, C.M. God's closed season: fishing under divine and secular authority in Mweru-Luapula Fishery, Zambia. Under review with Culture, Agriculture, Food and Environment (CAFE).

Beverton, R. and S.J. Holt. 1957. On the dynamics of exploited fish populations. London: HMSO.

Bos, A.R., C.K. Kapasa and P.A.M. van Zwieten. 2006. Update on the bathymetry of Lake Mweru (Zambia), with notes on water level fluctuations. African Journal of Aquatic Science 31(1): 145-150.

Camberlin, P. and N. Philippon. 2002. The East African March-May rainy season: associated atmospheric dynamics and predictability over the 1968-97 period. Journal of Climate 15(9): 1002-1019.

Carey, T.G. 1965. Lake Mweru-Luapula. In M.A.E. Mortimer (ed.). The fish and fisheries of Zambia. Lusaka: The Government Printer.

Chikwampu, P. 2005. US economist hails state over fish ban. Zambia Daily Mail, June 28.

Chisupa, K. 2004. Lake Mweru fish plunder worries fisheries official. Zambia Daily Mail, October 16.

Cunnison, I.G. 1959. The Luapula peoples of Northern Rhodesia: custom and history in tribal politics. Manchester: Manchester University Press.

Dezfuli, A.K. and S.E. Nicholson. 2013. The relationship of rainfall variability to western equatorial Africa to the tropical oceans and atmospheric circulation. Part II: the boreal autumn. Journal of Climate 26(1): 66-84.

Fauchereau, N., S. Trzaska, M. Rouault and Y. Richard. 2003. Rainfall variability and changes in Southern Africa during the 20th century in the global warming context. Natural Hazards 29(2): 139-154.

Feeny, D., F, Berkes, B.J. McCay and J.M. Acheson. 1990. The tragedy of the commons: twenty years later. Human Ecology 18(1): 1-19.

Gettleman, J. 2015. Meant to keep malaria out, mosquito nets are used to haul fish in. New York Times, January 24.

Gleick, J. 1997. Chaos: making a new science. New York: Penguin.

Gordon, D.M. 2005. Growth without capital: a renascent fishery in Zambia and Katanga, 1960s to recent times. Journal of Southern African Studies 31(3): 495-511.

Gordon, D.M. 2006. Nachituti's gift: economy, society, and environment in Central Africa. Madison, WI: University of Wisconsin Press.

Goudswaard, K. 1999. A dynamic fishery in Zambia: a case of change in the Mweru Luapula Fishery, Report of a frame survey in 1997. Nchelenge: Department of Fisheries.

Grimes, D., E. Coppola, M. Verdecchia and G. Visconti. 2003. A neural network approach to real-time rainfall estimation for Africa using satellite data. Journal of Hydrometeorology 4: 1119-1133.

Hardin, G.J. 1968. The tragedy of the commons. Science 162(3859): 1243-1248.

Harley, S.J., R.A. Myers and A. Dunn. 2001. Is catch-per-unit-effort proportional to abundance? Canadian Journal of Aquatic Science 58: 1760-1772.

Holling, C.S. 1986. The resilience of terrestrial ecosystems: local surprise and global change. In W.C. Clark and R.E. Munn (eds.). Sustainable development of the biosphere. Cambridge: Cambridge University Press.

Hulme, M., R. Doherty, T. Ngara, M. New and D. Lister. 2001. African climate change: 1900-2100. Climate Research 17(2): 145-168.

Jackson, P.B. 1961. The fishes of Northern Rhodesia: a check list of indigenous species. Lusaka: The Government Printer.

Jul-Larsen, E., J. Kolding, R. Overå, J.R. Nielsen and P.A.M. van Zwieten. 2003a. Management, comanagement or no management in southern African freshwater fisheries? In Jul-Larsen, E., J. Kolding, R. Overå, J.R. Nielsen and P.A.M. van Zwieten (eds.). Major dilemmas in southern African freshwater fisheries 1. Synthesis report. Rome: FAO.

Jul-Larsen, E., J. Kolding, R. Overå, J.R. Nielsen and P.A.M. van Zwieten. 2003b. Management, comanagment or no management? Major dilemmas in southern African freshwater fisheries: case studies. Rome: FAO. 
Jury, M., R.E. Matari and M. Matitu. 2009. Equatorial African climate teleconnections. Theoretical and Applied Climatology 95: 407-416.

Kaswende, K. 2005. Kalifungwa explains low catches of fish in Luapula. The Post, April 10.

Kolding, J. 1994. Plus ça change, plus c'est la même chose: on ecology and exploitation of fish in fluctuating tropical environments. Dr. Scient. Bergen: University of Bergen.

Kolding, J. and P.A.M. van Zwieten. 2011. The tragedy of our legacy: how do global management discourses affect small-scale fisheries in the south? Forum for Development Studies 38(3): 267-297.

Maboshe, S. 2004. Fish-ban enforcement and sensitization meetings tour report, 16th-21st June 2004. Mansa: Department of Fisheries.

Malama, B. 2004. State fears fish depletion in Luapula lakes, rivers. Zambia Daily Mail, July 2.

Marchant, R., C. Mumbi, S. Behera and T. Yamagata. 2007. The Indian Ocean dipole- the unsung driver of climatic variability in East Africa. African Journal of Ecology 45(1): 4-16.

McCay, B.J. and J.M. Acheson (eds.). 1987. The question of the commons: the culture and ecology of communal resources. Tuscon: University of Arizona Press.

McLean, K., A. Byanaku, A. Kubikonse, V. Tshowe, S. Katensi and A.G. Lehman. 2014. Fishing with bed nets on Lake Tanganyika: a randomized survey. Malaria Journal 13(1): 395-400.

Minakawa, N., G.O. Dida, G.O. Sonye, K. Futami and K. Satoshi. 2008. Unforeseen misuses of bed nets in fishing villages along Lake Victoria. Malaria Journal 7(1): 165-171.

Moonze, L. 2004. Fishing industry has collapsed, says Machungwa. The Post, February 26.

Musambachime, M.C. 1981. Development and growth of the fishing industry in Mweru-Luapula 1920-1964. Department of History seminar, University of Wisconsin Madison.

Nawa, K. 2000. Drought monitoring in Zambia using meteosat and NOAA Avhrr data. Asian conference on remote sensing, Taipei.

Nicholson, S.E. and A.K. Dezfuli. 2013. The relationship of rainfall variability in western equatorial Africa to the tropical oceans and atmospheric circulation. Part I: the boreal spring. Journal of Climate 26(1): 4565.

Paloheimo, J.E. and L.M. Dickie. 1964. Abundance and fishing success. Journal du Conseil (Conseil International pour l'Exploration de la Mer) 155: 152-163.

Plisnier, P-D., S. Serneels and E.F. Lambin. 2000. Impact of ENSO on East African ecosystems: a multivariate analysis based on climate and remote sensing data. Global Ecology and Biogeography 9(6): 481-497.

Roy, M., R.D. Holt and M. Barfield. 2005. Temporal autocorrection can enhance the persistence and abundance of metapopulations comprised of coupled sinks. The American Naturalist 166(2): 246-261.

Scullion, J. 1985. Development of the sardine fishery, Lake Mweru, Zambia. 1985: final report prepared for the States of Jersey Overseas Aid Committee. St. Helier, C.I. Nchelenge, Zambia: Department of Fisheries.

Verelst, B. 2013. Managing inequality: the political equality of a small-scale fishery, Mweru-Luapula, Zambia. Journal of Political Ecology 20(1): 14-36.

Waylen, P.R., C.M. Annear and Y. Qiu. 2011a. Estimating precipitation imputs into Lake Mweru, Zambia. Florida Climate Institute, annual meeting, Gainesville, FL.

Waylen, P.R., C.M. Annear and Y. Qiu. 2011b. Isabi, ilekonka menshi (a fish follows water): estimating annual precipitation inputs to the Lake Mweru basin, Zambia-Congo, and their spatial and temporal variability, 1925-86. Annual meeting of the southeastern division of the American Association of Geographers, Savannah, GA.

Williams, C.A. and N.P. Hanan. 2011. ENSO and IOD teleconnections for African ecosystems: evidence of destructive interference between climate oscillations. Biogeosciences 8: 27-40.

Williams, R. 1972. Relationship between the water levels and the fish catches in Lakes Mweru and Mweru wa Ntipa, Zambia. African Journal of Tropical Hydrobiology and Fisheries 2(1): 21-32.

Wilson, J.A., J. French, P. Kleban, S. McKay and R. Townsend. 1991. The management of chaotic fisheries: a bio-economic model. Proceedings from the symposium on multiple species fisheries, Copenhagen.

Zambia Daily Mail. 2005. Comment [maize prices, supply]. Zambia Daily Mail, August 18.

Zwieten, P.A.M. van, B.H.M. Aarnink and C.K. Kapasa. 1995. How diverse a fishery can be! Structure of the Mweru-Luapula fishery based on an analysis of the frame survey, 1992 and a characterization of the present management strategies. Nchelenge: Department of Fisheries. 
Zwieten, P.A.M. van, B.H.M. Aarnink, C.K. Kapasa and P. Ngalande. 1996. The biology, fishery and trade of chisense from Mweru-Luapula: status of present knowledge. Nchelenge: Department of Fisheries.

Zwieten, P.A.M. van, K. Goudswaard and C.K. Kapasa. 2003. Mweru-Luapula is an open exit fishery where a highly dynamic population of fishermen makes use of a resilient resource base. In E. Jul-Larsen, J. Kolding, R. Overå, J. Raakjaer Nielsen and P.A.M. van Zwieten (eds.). Management, co-management or no management: major dilemmas in southern African freshwater fisheries: case studies. Rome: FAO.

Zwieten, P.A.M. van and C.K. Kapasa. 1995. Lake Mweru Luapula. Analysis of the gillnet survey 1994. Nchelenge: Department of Fisheries. 